\title{
ANALISIS PENGENDALIAN MUTU DENGAN MENGGUNAKAN STATISTICAL QUALITY CONTROL (SQC) PADA PT.PRATAMA ABADI INDUSTRI (JX) SUKABUMI
}

\author{
Ira Andespa \\ Fakultas Ilmu Administrasi dan Humaniora Universitas Muhammadiyah \\ Sukabumi, Jawa Barat, Indonesia \\ E-mail : andespaira94@gmail.com
}

\begin{abstract}
The theme and main issues in this research are the ineffectiveness of the implementation of quality control applied to the company so that the high level of product defects or reject that exceeds the specified tolerance limit of $2.5 \%$. Then analyzed what are the factors causing the occurrence of defective products using statistical aids or statistical quality control (SQC) to minimize the occurrence of defective products at PT.Pratama Abadi Industri (JX) Sukabumi. The research method used by the author in this study uses quantitative descriptive method where the analysis technique used by the author is using statistical analysis techniques with 7 statistical tools or seven tools (check sheet, histogram, pareto diagram, scatter diagram, control chart, stratification, and causal diagram).From the results of research using the 7 statistical quality control tools that have been analyzed using a control map or P-Chart, it can be seen that the cause of irregularities that occur in PT. untidy stitches (22.19\%), torn rubber (16.67\%), fissures / boanding (15.68\%), Gross (15.89\%), faded logos (14.05\%), and accessories are swapped (15.53\%). As a result of the occurrence of irregularities, the company still produces products with quality that are included in the category of defects B-Grade $\neg$ and also C-Grade.
\end{abstract}

Keywords: Quality Control; Seven Tools; Statistical Quality Control (SQC).

\begin{abstract}
ABSTRAK
Tema dan pokok permasalahan yang ada pada penelitian ini yaitu belum efektifnya pelaksanaan pengendalian mutu yang di terapkan pada perusahaan sehingga masih tingginya tingkat produk cacat atau reject yang melebihin batas toleransi yang ditentukan yaitu sebesar 2,5\%. Kemudian dianalisis apa saja faktor penyebab terjadinya produk cacat menggunakan alat bantu statistik atau pengendalian mutu Statistical Quality Control (SQC) untuk meminimalisir terjadinya produk cacat pada PT.Pratama Abadi Industri (JX) Sukabumi. Metode penelitain yang digunakan oleh penulis dalam penelitian ini menggunakan metode deskriftif kuantitatif dimana teknik analisis yang digunakan penulis adalah menggunakan teknik analisis statistik dengan 7 alat bantu statistik atau seven tools (check sheet, histogram, diagram pareto, scatter diagram, peta kendali, stratifikasi, dan diagram sebab akibat). Dari hasil penelitian dengan menggunakan ke 7 alat pengendalian kualitas statistik yang telah dianalisa dengan menggunakan peta kontrol atau P-Chart dapat diketahui bahwa penyebab penyimpangan yang terjadi pada PT.:ratama Abadi Industri (JX) dari beberapa kerusakan yang terjadi yang paling berpengaruh adalah kerusakan jenis jahitan tidak rapih $(22,19 \%)$, rubber robek $(16,67 \%)$, lekang/boanding $(15,68 \%)$, Kotor $(15,89 \%)$, logo luntur $(14,05 \%)$,dan aksesoris tertukar $(15,53 \%)$. Akibat dari masih terjadinya penyimpangan tersebut perusahaan masih menhgasilkan produk dengan kualita yang masih termasuk dalam kategori cacat B-Grade dan juga $C$-Grade.
\end{abstract}

Kata kunci: Pengendalian Mutu; Seven Tools; Statistical Quality Control (SQC). 


\section{PENDAHULUAN}

Industri sepatu di Indonesia telah mengalami kemajuan signifikan, salah satu industri manufaktur yang mengalami kemajuan pesat di Indonesia adalah industri sepatu.Kondisi tersebut diawali dengan produsen sepatu dalam negeri yang masih rendah, kini telah berkembang menjadi produsen sepatu berskala besar yang mampu memproduksi sepatu berstandar internasional. Industri manufaktur memegang peranan penting didalam perekonomian Indonesia karena kemampuannya untuk menghasilkan produk yang dapat diperdagangkan dan membuka lapangan kerja (Silalahi,2014). Dalam kegiatannya industri manufaktur mengubah suatu barang dasar secara mekanis, kimia atau dengan menjadi barang jadi atau setengah jadi dan atau yang kurang nilainya menjadi barang yang lebih tinggi nilainya, dan sifatnya lebih dekat kepada pemakai akhir (Holzi dan Sogner,2004 dalam Darmawan Arif, 2016.

Kualitas merupakan faktor yang paling dasar untuk kepuasan konsumen Dalam memproduksi suatu barang tentunya perusahaan harus memperhatikan kualitas dengan tujuan keinginan konsumen dapat terpenuhi oleh perusahaan. Untuk menghasilakn kualitas produk yang baik kualitas produksi menjadi salah satu perhatian utama yang dilakukan oleh perusahaan dari mulai bahan baku, proses produksi hingga produk akhir. Dalam perkembangan dewasa ini, perusahaan dituntut untuk terus berinovasi meningkatkan efektivitas, efisiensi,dan kinerja pada perusahaa nya agar dapat bersaing dengan perusahaan lain. Setiap perusahaan yang memproduksi suatu barang tentunya harus memperhatikan kualitas mutu produk agar dapat memenuhi standar atau aturan untuk menilai apakah produk yang 
dihasilkannya itu masuk dalam katagori baik atau produk tidak baik / cacat / Not Good (NG).Produk cacat merupakan produk yang tidak maksimal atau tidak sesuai dengan standar mutu yang ditetapkan oleh perusahaan dalam proses pembuatannya. Produk cacat secara ekonomis dapat diperbaiki dengan menambah biaya tertentu yang menyebabkan perusahaan harus mengeluarkan biaya lebih besar dan rugi akibat tidak tidak terkendalinya produk cacat.

Meskipun dalam proses kegiatan produksi telah dilaksanakan sesuai dengan perencanaan perusahaan, namun pada kenyataannya masih banyak ketidaksesuaian antara produk yang di hasilkan dengan produk yang diharapkan misalnya masih banyak ditemukan barang cacat di akhir proses produksi padahal produk tersebut sudah melalui beberapa proses pengawasan mutu mulai dari pengawasan bahan baku,dan pengawasan proses produksi. untuk itu diperlukan pengendalian mutu pada perusahaan guna meminimalisisr kegagalan produk.

Pengendalian mutu merupakan bagian yang bertugas untuk menjamin mutu dari segi produk dan proses dengan melakukan pemeriksaan secara menyeluruh. Metode pengendalian menggunakan Statistik Quality Control (SQC) merupakan sistem yang dikembangkan untuk menjaga standar yang seragam dari kualitas hasil produksi, pada tingkat biaya yang minimum dan merupakan bantuan untuk mencapai efisiensi perusahaan. merupakan penggunaaan metode statistik untuk mengumpulkan dan menganalisis data dalam menentukan dan mengawasi kualitas hasil produksi secara efisien. Dengan adanya pengendalian mutu dan penggunaan metode statistik diharapkan memberikan dampak yang sangat signifikan terhadap kualitas produk akhir yang bisa memenuhi standar perusahaan juga bisa menjadi 
efisisensi biaya bagi perusahaan. Karena setiap perusahaan akan berusaha semaksimal mungkin menghasilkan produk yang dapat diterima dan memenuhi keinginan konsumen.

PT. Pratama Abadi Industri (JX) Sukabumi merupakan salah satu perusahaan yang ada di kabupaten Sukabumi. Berdasarkan akte pendirian yang dikeluarkan oleh Menteri Kehakiman Republik Indonesia dengan surat keputusan tanggal 2 Februari 1993 yang disetujui oleh Menteri Kehakiman Republik Indonesia dengan surat keputusan tertanggal 20 Agustus 1993 No 02/7334/HT/01/04/1993. PT. Pratama Abadi Industri (JX) berlokasi di jalan sukabumi-cianjur km.14, blok satong parigi Desa Titisan Kec.Sukalarang Kab. Sukabumi Provinsi Jawa Barat. PT.Pratama Abadi Industri (JX) Sukabumi adalah perusahaan yang bergerak dalam industri produksi sepatu olahraga. Hasil produksi sepatu perhari sekitar 12.000 pasang sepatu. penulis menemukan adanya permasalahan mengenai pengendalian mutu. Pengendalian mutu di PT.Pratama Abadi Industri (JX) dianggap belum efektif sehingga perusahaan masih mengalami kecacatan produk Namun dari sekian banyak produk yang dihasilkan masih terjadi penyimpangan standar kualitas atau produk cacat yang masih ada di dalam kategori grade rendah (grade- $B$ ) dan tidak sedikit yang mengalami kegagalan total produk (grade-C), hal ini menimbulkan adanya ketidaksesuaian produk yang di harapakan oleh perusahaan. Produk cacat yang sering terjadi adalah masih terdapat penyimpangan-penyimpangan produk yang lolos dari rangkaian pengawasan mutu meskipun produk tersebut sudah di nyatakan baik. Hal ini di duga disebabkan oleh beberapa faktor diantaranya: manusia, bahan baku, mesin, metode dan lingkungan. 
Produk cacat adalah produk yang dihasilakn dalam proses produksi, namun tidak maksimal atau tidak sesuai dengan standar mutu yang ditetapkan oleh perusahaan, tetapi secara ekonomis produk tersebut masih dapat diperbaiki dengan mengeluarkan biaya tertentu atau tambahan biaya. Kategori produk cacat menurut (Sujana (2017) dikutip dalam jurnal Riska Fauziah (2017 : 23) "kategori produk cacat merupakan proses pemisahan barang dimana terdapat ke dalam beberapa toleransi yang masih dapat di terima atau tidak di terima oleh konsumen. Adapun jenis permasalahan produk cacat yang sering terjadi pada perusahaan manufaktur terutama bagian departemen assembling”. Berdasarkan jenis produk cacat di atas , peneliti mengklasifikasikan jenis kualitas yang ada pada perusahaan menjadi beberapa kategori atau Grade yaitu Grade-A, B-Grade, dan C-Grade.

Produk A-Grade : Merupakan sepatu layak jual tanpa adanya kerusakan fungsional dan kosmetik. Serta tidak menyebabkan gangguan ketika sepatu dipakai. Produk B-Grade : Merupakan sepatu layak jual tanfa kerusakan fungsional, namun memiliki kecacatan kosmetik yang tidak dapat diperbaiki secara sempurna dan termasuk cacat major, karena berdampak pada potongan harga sebesar 40-50\% dan hanya dapat dijual di factory outlet tertentu. Produk C-Grade : Merupakan sepatu yang tidak layak jual, dikarenakan, sepatu yang dihasilkan memiliki kerusakan baik secara fungsional maupun secara kosmetik, yang menyebabkan ketidaknyamanan ketika dipakai.

Konsep mutu atau kualitas pada industri manufaktur. Kualitas pada industri manufaktur mengalami perkembangan pesat untuk itu para pelaku bisnis harus terus berinovasi dan mampu menciptakan keunggulan baru terhadap produknya. 
Perusahaan harus terus memperhatikan kualitas hasil produksinya dengan terus menerus mengadakan perbaikan pada kualitas produk yang dihasilkan.

Peranan kualitas menjadi sangat penting pada perusahaan karena produk yang akan dijual harus memiliki jaminan kualitas terbaik agar perusahaan tidak kehilangan pelanggan, sebaliknya jika perusahaan tidak memperhatikan kualitas produk yang dihasilkan akibatnya produk kurang di minati oleh pelanggan di pasaran. Menurut Russel (1996) dalam jurnal Dan Ria Asysyfa Hasni (2013:2) terdapat enam peran penting kualitas pada perusahaan yaitu : 1). Meningkatkan reputasi perusahaan. 2). Menurunkan biaya. 3). Meningkatkan pangsa pasar. 4). Dampak internasional. 5). Adanya pertanggung jawaban produk. 6). Untuk penampilan produk atau jasa dan Mewujudkan kualitas yang dirasakan penting

Secara umum kualitas atau mutu dapat diartikan sebagai suatu jumlah karakteristik yang baik sesuai dengan keinginan konsumen sebagai kecocokan penggunaan dan nilai yang diterima dalam kepuasan pelanggan. Setelah mengetahui dari beberapa pengertian pengendalian dan mutu atau kualitas, selanjutnya akan dikemukakan pengertian pengendalian mutu menurut beberapa ahli diantaranya

Pengertian pengendalian menurut Sofjan Assauri (2004:210) adalah “pengawasan mutu merupakan usaha untuk mempertahankan mutu atau kualitas dari barang yang dihasilkan, agar sesuai dengan spesifikasi produk yang telah ditetapkan berdasarkan kebijakan pimpinan perusahaan” 
Menurut C. Rudy Prihantoro(2012:6) yang dimaksud dengan pengendalian mutu yaitu: "Suatu sistem kendali yang efektif untuk mengkoordinasikan usahausaha penjagaan kualitas, dan perbaikan mutu dari kelompok-kelompok dalam organisasi produksi, sehingga diperoleh suatu produksi yang sangat ekonomis serta dapat memuaskan kebutuhan dan keinginan konsumen".

Sedangkan Pengertian pengendalian menurut Vincent Gasperzs (2003:480) yaitu "Quality control is the opratioal techniques and avtivities used to fulfill requirements for quality.” Berdasarkan pengertian para ahli diatas menjelaskan bahwa yangdimaksud dengan pengendalian mutu adalah suatu aktivitas yang efektif untuk mempertahankan mutu atau kualitas dari barang yang dihasilkan serta efektif untuk mengkoordinasikan usaha-usaha dari kelompok produksi untuk memuaskan kebutuhan konsumen.

Menurut Sofjan Assauri dikutip dalam jurnal Bakhitar Suharto Tahir Dan Ria Asysyfa Hasni (2013:30) faktor - faktor yang mempengaruhi pengendalian kualitas yang dilakukan perusahaan adalah: 1). Kemampuan Proses : Batas-batas yang ingin dicapai haruslah disesuaikan dengan kemampuan proses yang ada. 2). Spesifikasi yang Berlaku :Hasil produksi yang ingin diapai harus dapat berlaku sebelum pengendalian kualitas pada proses dapat dilaksanakan. 3). Tingkat Ketidaksesuaiaan Dapat Diterima : Tujuan dari dilakukannya pengendalian adalah untuk mengurangi produk cacat atau dibawah standar sekecil mungkin, maka dari itu tingkat pengendalian yang berlaku tergantung pada banyaknya produk yang berada di bawah standar. 4). Biaya Kualitas : Biaya menjadi tolak ukur yang paling mempengaruhi tingkat pengendalian dalam menghasilkan produk yang berkualitas, 
biaya memiliki hubungan yang positif ketika makin tinggi kualitas produk yang dihasilkan maka semakin besar biaya yang dikeluarkan.

Statistical Quality Control (SQC) merupakan sistem yang dikembangkan untuk menjaga standar yang seragam dari kualitas hasil produksi, pada tingkat biaya yang minimum dan merupakan bantuan untuk mencapai efisiensi perusahaan. Menurut Sofjan Assauri (2004) dalam jurnal Syarif (2017:22) mengemukakan bahwa : "Pengendalian kualitas statistik atau statistical quality qontrol (SQC) adalah suatu sistem yang dikembangkan untuk menjaga standar yang seragam dari kualitas hasil produksi, pada tingkat biaya yang minimum, dan membantu mewujudkan sitem produksi secara efisien".

Pengendalian kualitas secara statistik atau statistical quality control (SQC) digunakan untuk menemukan kesalahan produk yang mengakibatkan produk cacat Baktiar,dkk (2013:2498). Pada dasarnya SQC merupakan penggunaaan metode statistik merupakan teknik pengambilan keputusan pada suatu analisa informasi yang terkandung dalam sebuah sampel dari sejumlah populasi. Metode statistik dapat menjamin kualitas serta dapat membrikan cara-cara pokok dalam pengambilan sampel produk, pengujian, serta pengambilan langkah perbaikan selanjutnya.

Aktivitas pengendalian kualitas merupakan teknik untuk mengukur karakteristik kualitas dari suatu produk atau jasa, kemudian akan dibandingkan dengan standar keinginan produk yang telah ditentukan, apabila ditemukan perbedaan kinerja kualitas dengan standar yang telah ditentukan makan akan 
dilakukan tindakan penginkatan kualitas yang tepat guna mewujudkan spesifikasi produk yang di inginkan.

Pengendalian kualitas produksi dapat dilakukan dengan berbagai cara yang tepat misalnya penggunaan bahan yang berkualitas, sistem mesin yang sudah sangat canggih, tenanga kerja yang sudah sangat trampil dan proses produksi yang sudah tepat dengan standar oprasional prosedure (SOP). Penggunaan Statistical Quality Control (SQC) digunakan untuk menemukan kesalahan-kesalahan yang menyebabkan produk yang dibuat dalam proses produksi kurang maksial sehingga produk masih berada dalam kualitas B-grade dan yang paling parah produk mengalami kegagalan total atau bisa disebut dengan kegagalan C-grade. Sehingga sebelum itu terjadi dapat diambil tindakan untuk mengatasinya.

Statistical Quality Contro (SQC) dignakan dalam mengendalikan dan mengelola proses baik dalam perusahaan manufaktur maupun jasa melalui beberapa metode statistik. Alat bantu dalam pelaksanaan pengendalian kualitas atau teknik pengendalain mutu merupakan alat untuk mendeteksi sebab-sebab terjadinya penyimpangan diluar kendali dalam proses produksi dan cara bagaimana untuk melakukan tindakan perbaikan. Metode SQC terdapat dua cara yaitu dengan menggunakan peta kendali (control chart) dan diagram tulang ikan (fishbone chart)

Metode SQC yang digunakan pada penelitain ini menggunakan metode peta kontrol atau control chart, Peta kontrol adalah salah satu metode statistik yang dapat digunakan untuk memberi informasi dalam meningkatkan atau memperbaiki kualitas bentuk dasar peta kontrol atau control chart merupakan grafik suatu karakteristik mutu yang telah diukur dari suatu sampel. 
Pada penyelesaian akhir terdapat tujuh macam alat pengendalian kualitas yang dalam penerapannya dapat digunakan seluruhnya maupun sebagian tergantung kebutuhan masing-masing perusahaan. Menurut C.Rudy. Prihantoro (2012) dalam Riska Agustin (2017:98) alat bantu pengendalian kualitas atau yang dikenal sebagai seven tools adalah sebagai berikut: 1). Lembar pengamatan atau check sheet. 2). Stratifikasi. 3). Histogram (run chart). 4). Grafik kendali (control chart). 5). Diagram pareto. 5). Diagram sebab akibat (cause and effect diagram). 6). Diagram sebar (scatter diagram)

\section{METODE PENELITIAN}

Penelitian ini dilaksanakan di PT.Pratama Abdi Industri (JX) Sukabumi dengan menggunakan metode deskriptif kuantitatif serta data-data yang digunakan untuk menganalisis kerusakan produk sepatu dengan menggunakan metode statistical quality control (SQC) dan teknik pengumpulan data dilakukan meliputi:

Data primer merupakan data yang diperoleh atau dikumpulkan langsung di lapangan oleh orang yang melakukan penelitian atau yang bersangkutan yang memerlukannya. Adapun data primer yang dibutuhkan dalam penelitian pada perusahaan PT.Pratama Abadi Industri (JX) Sukabumi terdiri dari:

Observasi : merupakan proses pencacatatan pola prilaku (orang), objek (benda) atau kejadian yang sistematik tanpa adanya pertanyaan atau komunikasi dengan masing-masing individu yang diteliti, pada penelitian ini observasi dilakkan dengan cara melihat atau terjun langsung melihat proses produksi sepatu. Wawancara Terstruktur : wawancara terstruktur digunakan sebagai teknik 
pengumpulan data, bila peneliti atau pengumpul data telah mengetahui dengan pasti tentang informasi apa yang akan diproleh. Oleh karena itu dalam melakukan wawancara, pengumpulan data telah menyiapakan instrument penelitian berupa pertanyaan-pertanyaan tertulis. Wawancara Tidak Terstruktur. Wawancara tidak terstruktur adalah wawancara yang bebas dimana penelitian tidak menggunakan pedoman wawancara yang telah tersusun secara sistematis dan lengkap. Peneliti melakukan wawancara dengan pihak Departement Quality dan Kepala Produksi Stockfiti PT.Pratama Abadi Industri (JX) Sukabumi dan juga kepada beberapa karyawan yang berada pada perusahaan tersebut secara tidak sengaja.

Data sekunder umumnya berupa bukti, catatan atau laporan berupa laporan historis yang telas tersusun dalam arsip (data dikumenter) atau daily baik yang dipublikasikan maupaun yang tidak di dokumentasikan. Data ini dapat diperoleh dengan cara meminta langsung dari perushaan. Adapun data sekunder yang dibutuhkan dalam penelitian pada perusahaan PT.Pratama Abadi Industri (JX) Sukabumi adalah sebagai berikut : 1). Data jumlah hasil produksi per/bulan. 2). Data jumlah produk cacat per/bulan. 3). Data jumlah produk cacat tipe B-grade per/bulan. 4). Data jumlah produk cacat tipe C-Grage per/bulan

Terdapat tujuh alat bantu yang diperkenankan dalam metode statistik atau Statistical Quality Control (SQC), Metode ini digunakan untuk mengantisipasi terjadinya kesalahan atau cacat dengan menggunakan langkah-langkah terukur dan terstruktur, berdasarkan data yang ada. Dari tujuh alat bantu yang diperkenankan peneliti hanya akan memakai beberapa teknik analis dan menelaah nya hanya dengan cara pemecahan masalah dengan menganalisis menggunakan lembar 
periksa atau check sheet, histogram, peta kendali, diagram pareto dan hubungan sebab akibat menggunakan diagram tulang ikan atau cause and effect diagram.

Adapun langkah-langkah analisis yang dilakukan peneliti dalam pemecahan masalah ini diantaranya adalah: 1). Menentukan masalah yang sedang dihadapi oleh perusahaan yang bersangkutan, dalam penelitian ini masalah yang dihadapi adalah banyaknya ketidaksesuaian. 2). produk yang terjadi di akhir proses pengemasan sepatu pada proses finishing product. 3). Mencatat jumlah produk reject atau cacat sesuai dengan apa yang terjadi pada perusahaan dengan menggunakan Check Sheet. 4). Mengklasifikasikan persoalan menjadi unsur-unsur tabulasi data berdasarkan ukurannya dengan menggunakan Histogram. 5). Mengindentifikasi setiap kondisi yang tidak terkendali secara statistik dengan control chart. Rumus yang digunakan dalam control chart atau peta kendali pada penelitian ini yaitu peta kendali $\mathrm{P}$.

Adapun langkah-langkah dalam membuat peta kendali $\mathrm{p}$ adalah sebagai berikut: a). Mencatat dan mengumpulkan data untuk setiap sub grup tentang jumlah yang diperiksa dan jumlah yang ditolak. b) . Menghitung proporsi kerusakan $\mathrm{p}$ untuk setiap sub grup, yaitu :

$$
P=\frac{\text { Jumlahcacat }}{\text { UkuranJumlahsub group }}=\frac{n P}{n}
$$

Keterangan:

$\mathrm{p}$ : Proporsi kerusakan

$n p:$ Jumlah gagal dalam sub grup

$n$ : Jumlah yang diperiksa dalam sub grup 
Menghitung garis pusat / Central $\sum$ Line (CL)

$$
\mathrm{CL}=\bar{p}=\frac{\text { Jumlah yang cacat total }}{\text { jumlahtotal yang diperiksa }}=\frac{\sum n P}{\sum n}
$$

Keterangan :

Knp : Jumlah total yang cacat

$\sum \mathrm{n} \quad$ : Jumlah total yang diperiksa

Menghitung batas kendali atas atau Upper Control Limit (UCL)

$$
\mathrm{UCL}=\bar{p}+3 \sqrt{\frac{\bar{P}(1-\bar{P})}{n}}
$$

Keterangan :

$\bar{P} \quad$ : Jumlah ketidak sesuaian produk

n : Jumlah produksi

Menghitung batas kendali bawah atau Lower Control Limit (LCL). Untuk menghitung batas kendali bawah atau LCL dilakukan dengan rumus:

$$
\mathrm{LCL}=\bar{P}-3 \sqrt{\frac{\bar{P}(1-\bar{P})}{n}}
$$

Keterangan :

LCL : Batas kendali bawah atau Lower control limit (LCL)

$\bar{P} \quad$ : Rata-rata ketidaksesuaian produk

n : Jumlah produksi

f). Menggambarkan peta kendali dimana garis vertikal adalah jumlah presentase produk gagal, sedangkan garis horizontal menunjukan sampel atau waktu pemeriksaan. Selanjutnya gambarkan garis tengah berupa p rata-rata, batas atas dan batas bawah bertujuan untuk mengetahui batas daerah pengendalian atau batas toleransi kegagalan produk. g). Setelah digambarkan produk UCL dan LCL maka cantumkanlah presentase produk gagal berupa titik kemudian hubungkan setiap 
titik tersebut untuk mengetahui apakah ada titik melewati batas atas dan batas bawah. Jika terlihat adanya titik berati terdapat penyimpangan dari batas toleransi produk gagal yang telah di tetapkan. 6). Menentukan prioritas perbaikan menggunakan diagram pareto (pareto chart). 7). Mencari faktor penyebab yang dominan menggunakan diagram sebab akibat (cause and effect diagram). 8). Membuat rekomnedasi usulan perbaikan kualitas : pada tahap ini yaitu membahas tentang perolehan hasil pengolahan data untuk diketahui penyebab teradinya kerusakan produk, dan menyusun rekomendasi atau usulan tindakan perbaikan selanjutnya. 9). Kesimpulan akhir : merupakan hasil dari analisisi melalui semua metode perbaikan yang dipakai yaitu metode mana yang terbaik untuk dapat diterapkan pada perusahaan.

\section{HASIL DAN PEMBAHASAN}

Berdasarkan hasil wawancara yang dilakukan tersebut, peneliti juga melakukan wawancara tentang penyimpangan-penyimpangan yang sering disebut dengan produk cacat. Adapun gambaran klasifikasi jenis - jenis produk cacat atau reject yang ada di perusahaan diantaranya yaitu: 1). Rubber Robek, yaitu bahan material yang akan di gunakan sebagai bahan dasar atau bawahan sepatu rapuh , mudah robek dapat dikatakan robek apabila ketika material di regangkan dengan tangan bentuknya tidak elastik atau tidak kembali pada bentuk semula. 2). Lekang / Boanding yaitu lem yang kurang kuat sehingga ketika di tekuk masih terlihat adanya retakan. 3). Kotor yaitu terlihat masih banyak sepatu yang kotor akibat kena noda yang sulit di bersihkan misal terkena makanan dari tangan operator yang menempel pada produk akibat kurang di jaga kebersihannya. 4). Jahitan tidak rapi 
/ over stitching yaitu jahitan yang mengalami lubang jarum atau hasil jahitan yang kurang rapih. 5). Logo luntur diakibatkan oleh suhu mesin yang terlalu panas menyebakan logo mengelupas atau luntur. 6). Aksesoris tertukar, yaitu pada pemasangan akresoris seperti cara mengikat tali sepatu tidak sesuai dengan jenis atau style sepatu yang akan di pasangkan.

Tema dan pokok permasalahan yang ada pada penelitian ini yaitu belum efektifnya pelaksanaan pengendalian mutu yang di terapkan pada perusahaan sehingga masih tingginya tingkat produk cacat atau reject yang melebihin batas toleransi yang ditentukan yaitu sebesar 2,5\%. Kemudian dianalisis apa saja faktor penyebab terjadinya produk cacat menggunakan alat bantu statistik bantu statistik seven tools. (lembar pengecekan atau check sheet, statifikasi, histogram, diagram pareto,diagram peta kendali $\mathrm{p}$, diagram sebar, dan diagram sebab akibat).

Adapun hasil pengamatan data melalui check sheet yang telah dilakukan dapat terlihat seperti pada Tabel 1.

Tabel 1.

Data Jumlah Produksi dan Produk Cacat Pada PT.Pratama Abadi Industri (JX) Sukabumi Bulan Januari-November 2019

\begin{tabular}{cccccc}
\hline Bulan & $\begin{array}{c}\text { Jumlah } \\
\text { Produksi }\end{array}$ & $\begin{array}{c}\text { Cacat } \\
\text { B-Grade }\end{array}$ & $\begin{array}{c}\text { Cacat } \\
\text { C-Grade }\end{array}$ & $\begin{array}{c}\text { Jumlah Produk } \\
\text { cacat / reject }\end{array}$ & $\begin{array}{c}\text { Presentase } \\
\text { Produk Cacat / } \\
\text { Riject (NG) }\end{array}$ \\
\hline Jan-19 & 577.550 & 53.942 & 686 & 54.628 & $9,46 \%$ \\
Feb-19 & 575.250 & 32.203 & 471 & 32.674 & $5,68 \%$ \\
Mar-19 & 557.625 & 43.821 & 175 & 43.996 & $7,89 \%$ \\
Apr-19 & 465.576 & 46.902 & 674 & 47.576 & $10,22 \%$ \\
Mei-19 & 449.975 & 58.603 & 997 & 59.600 & $13,25 \%$ \\
\hline
\end{tabular}


Lanjutan

Tabel 1.

Data Jumlah Produksi dan Produk Cacat Pada PT.Pratama Abadi Industri (JX) Sukabumi Bulan Januari-November 2019

\begin{tabular}{cccccc}
\hline Bulan & $\begin{array}{c}\text { Jumlah } \\
\text { Produksi }\end{array}$ & $\begin{array}{c}\text { Cacat } \\
\text { B-Grade }\end{array}$ & $\begin{array}{c}\text { Cacat } \\
\text { C-Grade }\end{array}$ & $\begin{array}{c}\text { Jumlah Produk } \\
\text { cacat / reject }\end{array}$ & $\begin{array}{c}\text { Presentase } \\
\text { Produk Cacat / } \\
\text { Riject (NG) }\end{array}$ \\
\hline Jun-19 & 584.625 & 47.092 & 321 & 47.413 & $8,11 \%$ \\
Jul-19 & 525.750 & 33.462 & 291 & 33.753 & $6,42 \%$ \\
Agu-19 & 472.570 & 55.342 & 228 & 55.570 & $11,76 \%$ \\
Sep-19 & 600.375 & 58.963 & 414 & 59.377 & $9,89 \%$ \\
Okt-19 & 601.850 & 48.673 & 302 & 48.975 & $8,14 \%$ \\
Nov-19 & 600.752 & 47.532 & 318 & 47.850 & $7,97 \%$ \\
\hline
\end{tabular}

Sumber: PT.Pratama Abadi Industri (JX) Sukabumi, Data Diolah Sendiri

Stratifikasi (Run chart) bertugas dalam persoalan menjadi kelompok atau golongan sejenis rincian atau hal lebih kecil menjadi unsur-unsur tunggal dari persoalan. Untuk memudahkan pemaaman, pengklasifikasian/pengelompokan jenis masalah menjadi komponen kecil maka stratifikasi perlu dilakukan.

Histogram merupakan tabulasi data yang diatur berdasarkan ukurannya, hal ini bertujuan untuk memudahkan dalam melihat lebih jelas prduk cacat / reject yang terjadi sesuai dengan tabel diatas, maka disajikan ke histogram yaitu dalam bentuk grafik balok. 


\section{Histogram}

800,000

600,000

400,000

200,000
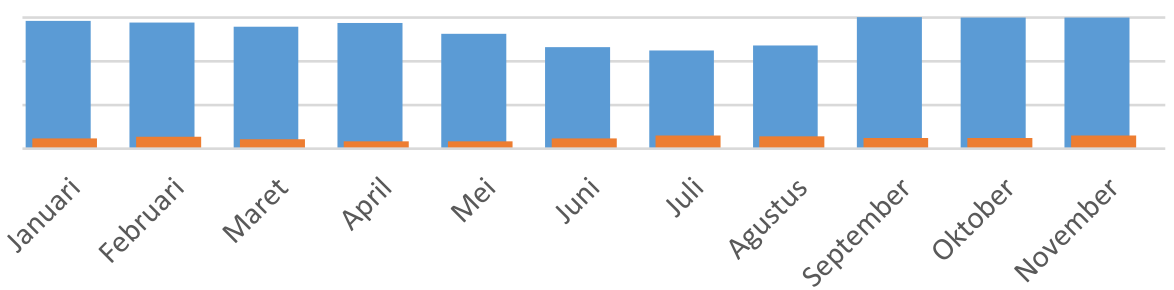

Sumber : Data Diolah Sendiri Menggunakan Microsoft Excel.

\section{Grafik 1.}

\section{Hasil Grafik Histogram}

Diagram pareto (pareto chart) merupakan diagram yang digunakan untuk mengidentifikasi, mengurutkan, dan bekerja untuk menyisihkan pada produk cacat atau not good secara secara permanen. Dengan diagram ini, maka dapat diketahui jenis cacat yang paling dominan pada hasil produksi selama bulan januari 2019 sampai dengan bulan november 2019 .

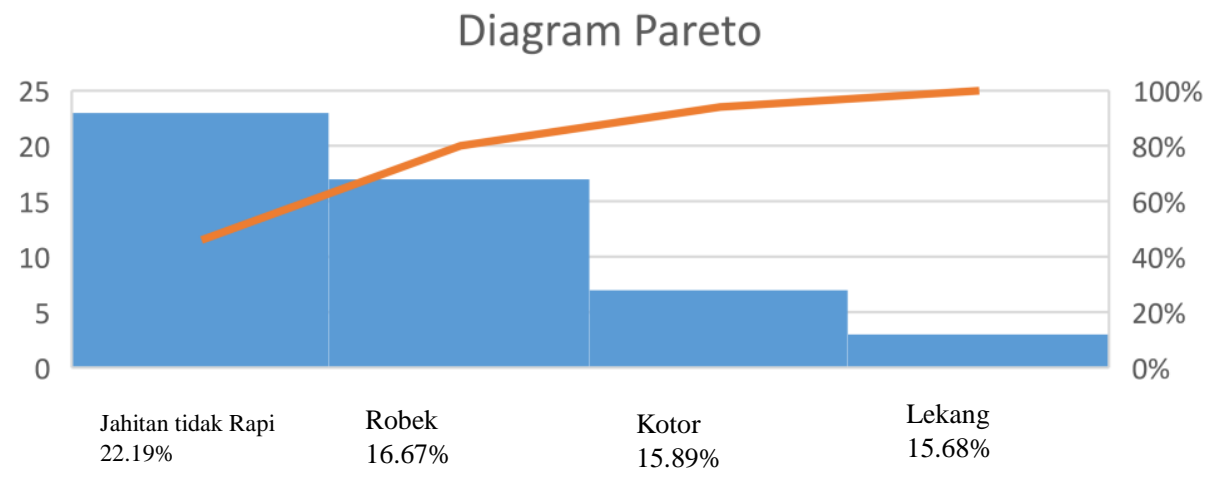

Sumber : Data Diolah Sendiri Menggunakan Microsoft Excel

Grafik 2.

Hasil Diagram Pareto (Pareto Chart) 
Dapat di dimpulkan jenis cacat yang paling besar pada produk sepatu merk nike periode Januari-November 2019 adalah jenis cacat jahitan tidak rapi sebesar 22,19\%. Dan persentase kumulatifnya $22,19 \%$ yang ditimbulkan akibat operator/pekerja bagian jahit atau terdapat kerusakan pada mesin jahitnya itu sendiri. Jumlah cacat kedua adalah jenis cacat robek dengan jumlah persentase cacat sebesar $16,67 \%$ dengan persentase kumulatifnya sebesar $38,86 \%$. Ketiga ada jumlah cacat yang disebabkan oleh jenis cacat kotor denga jumlah presentase cacat sebesar $15,89 \%$ dengan persentase kumulatif sebesar $54,74 \%$. Jumlah cacat keempat disebabkan oleh jenis cacat lekang atau bonding dengan pesentase $15,68 \%$ dan persentase kumulatifnya sebesar $70,42 \%$. Selanjutnya disebabkan oleh jenis cacat logo sepatu yang luntur mempunyai persentase cacat sebesar $14,05 \%$ dengan persentase kumulatif $100,00 \%$ dan yang terakhir dengan jenis cacat aksisoris tertukar dengan total persentase sebesar $15,53 \%$ sedangkan untuk total persentase kumulatif $85,95 \%$.

Hasil Peta Kendali (Control Chart). Peta kendali /Control Chart adalah cara untuk mengidentifikasi setiap kondisi yang tidak terkendali secara statistik. Oleh karena itu akan dianalisis kembali mengunakan peta kendali $\mathrm{p}$ melalui grafik kendali statistik (control chart) yang mempunyai manfaat untuk membantu fungsi dalam mengukur proporsi kerusakan (cacat). Adapun langkah-langkah untuk membuat peta kendali $\mathrm{p}$ adalah sebagai berikut:

Manghitung proporsi produk cacat

$$
p=\frac{n p}{n}
$$

\section{Keterangan :}

$\mathrm{p} \quad$ : rata-rata ketidak sesuaian untuk sub grup 
$\mathrm{np} \quad$ : jumlah gagal dalam subgrup

$\mathrm{n} \quad$ : jumlah yang diperiksa dalam sub grup

Maka perhitungan datanya adalah sebagai berikut:

Subgrup $1 \quad: p=\frac{n p}{n}=\frac{54628}{577550}=0,09$

Subgrup $2: p=\frac{n p}{n}=\frac{32674}{575250}=0,06$

Subgrup $3: p=\frac{n p}{n}=\frac{43996}{557625}=0,08$

Dan seterusnya ....

Dari hasil tersebut menyatakan bahwa rata-rata ketidak sesuaian untuk

Subgrup 1 yaitu 0,09 untuk Subgrup 2 yaitu 0,05 dan untuk Subgrup 3 yaitu 0,07.

Menentukan kelayakan barang itu dikirim ke konsumen atau tidak.

Menghitung Garis Pusat / Center Line (CL)

Garis pusat atau CL yang merupakan rata-rata kerusakan produk $(\bar{p})$ dilakukan dengan cara berikut:

$\mathrm{CL}=\bar{p}=\frac{\sum n P}{\sum n}$

Keterangan:

$\Sigma \mathrm{np}=$ jumlah total gagal

$\sum \mathrm{n} \quad=$ jumlah total yang diperiksa

Maka perhitungannya adalah :

$\mathrm{CL}=\bar{p}=\frac{531.412}{6.011 .898}=0,08$

Dari hasil tersebut menyatakan garis pusat sebagai acuan yaitu 0,08. Artinya

produk cacat yang dihasilkan mengacu kepada garis pusat yang ditentukan berdasarkan perhitungan tersebut.

Menghitung Batas Kendali Atas atau Upper Control Limit (UCL)

Untuk menhitung batas kendali atas atau UCL dilakukan dengan rumus :

$\mathrm{UCL}=\bar{p}+3 \sqrt{\frac{\bar{P}(1-\bar{P})}{n}}$

Keterangan :

$\bar{p} \quad=$ rata-rata ketidaksesuaian produk

$\mathrm{n} \quad=$ jumlah produksi 
Untuk perhitungannya adalah :

Subgrup $1 \quad:$ UCL $=0.08+3 \sqrt{\frac{0.08(1-0.08)}{577.550}}=84.303$

Subgrup $2 \quad: \mathrm{UCL}=0.08+3 \sqrt{\frac{0.08(1-0.08)}{575.250}}=84.303$

Subgrup $\quad: \mathrm{UCL}=0.08+3 \sqrt{\frac{0.08(1-0.08)}{557.625}}=84.303$

Dan seterusnya....

Dari hasil tersebut menyatakan bahwa batas kendali atas untuk Subgrup 1 yaitu, 0.68 Subgrup 2 yaitu, 0.68 dan Subgrup 3 yaitu 0.68. Artinya produk cacat yang dihasilkan mempunyai batas kendali atas (maksimum) untuk mengendalikan dan mengambil tindakan untuk melakukan perbaikannya.

Menghitung Batas Kendali Bawah atau Lower Control Limit (LCL)

Untuk menghitung batas kendali bawah atau LCL dapat dilakukan dengan rumus :

$\mathrm{LCL}=\bar{p}-3 \sqrt{\frac{\bar{P}(1-\bar{P})}{n}}$

Keterangan :

$\bar{p} \quad=$ rata-rata ketidaksesuaian produk

$\mathrm{n} \quad=$ jumlah produksi

Maka perhitungannya adalah :

Subgrup 1 : LCL $=0.08-3 \sqrt{\frac{0.08(1-0.08)}{577.550}}=12.221$

Subgrup 2: LCL $=0.08-3 \sqrt{\frac{0.08(1-0.08)}{575.250}}=12.221$

Subgrup $3: \mathrm{LCL}=0.08-3 \sqrt{\frac{0.08(1-0.08)}{557.625}}=12.221$

Dan seterusnya....

Catatan : Jika LCL $<0$ maka dianggap $\mathrm{LCL}=0$

Dari hasil tersebut menyatakan bahwa batas kendali bawah untuk Subgrup 1 yaitu 0.06 , Subgrup 2 yaitu 0.06 dan Subgrup 3 yaitu 0.06. Artinya produk cacat 
yang hasilkan mempunyai batas kendali bawah (minimum) untuk mengendalikan dan mengambil tindakan untuk melakukan perbaikannya. Untuk hasil perhitungan yang selengkapnya dapat di lihat pada Grafik 3.

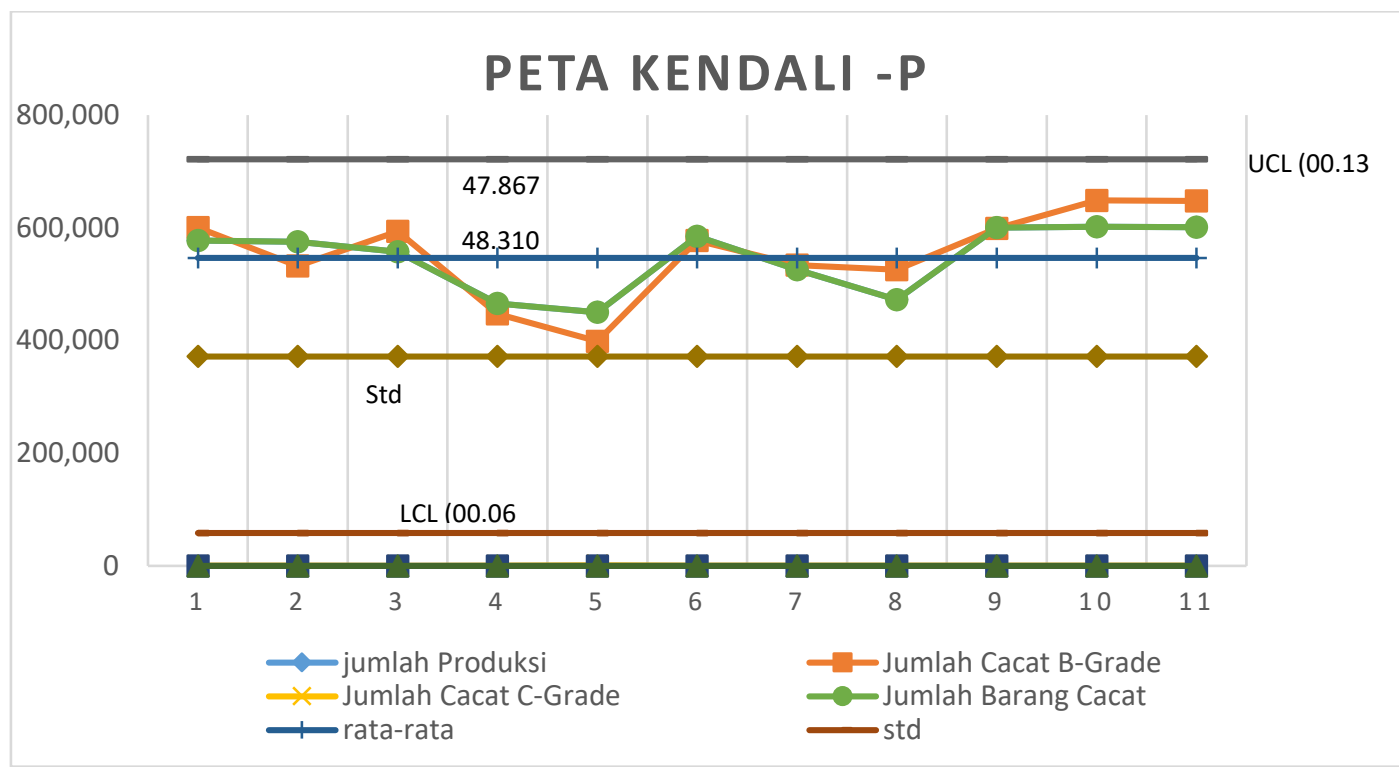

Sumber : Data Diolah Sendiri Menggunakan Microsoft Excell

Grafik 3.

Hasil Peta kendali -P Periode Januari- November 2019

Berdasarkan Grafik 3 dapat dilihat bahwa jumlah produk gagal dari bulan Januari sampai bulan November 2019 tidak terdapat penyimpangan dari batas pengendalian atau toleransi yang ditetapkan, namun perlu di waspadai bahwa ada sedikit mendekati penyimpangan batau bawah (LCL) yang di sebabkan oleh barang cacat jenis B-Grade baik dari (batas kendali atas/UCL dan batas bawah/LCL)

Faktor-faktor yang mempengaruhi produk cacat menurut Endah (2001) dalam Miftahul Janah (2017:123) Ada beberapa faktor yang mempengaruhi terjadinya produk cacat dalam proses produksi suatu perusahaan, yaitu: 1). Sumber daya manusia tidak terlepas dari kesalahan-kesalahan seperti ketidaktelitian, 
kecerobohan, kurangnya konsesntrasi, kelelahan, dan kurangnya disiplin serta rasa tanggung jawab yang mengakibatkan terjadinya produk yang tidak sesuai standar perusahaan. 2). Bahan baku sangat mempengaruhi kualitas produk yang akan dihasilkan.3). Mesin adalah salah satu alat yang mempengaruhi terjadinya produk rusak. Karena untuk menghasilkan produk dengan kualitas baik diperlukan mesinmesin yang baik dan terawat dengan baik.

Untuk menanalisis lebih lanjut penulis terus mencari penyebab kegagaln ini sampai hal terkecil salah satunya menganalisis lebih mendalam dengan menggunkaan diagram sebab akibat atau disebut Cause Anf Effect Diagram. Diagram sebab akibat dapat digunakan untuk menggambarkan elmen-elmen proses analisis secara menyuluruh. Dengan kata lain diagram sebab akibat ini dapat memperlihatkan hubungan antara permasalahan dengan permasalahan yang dihadapi dengan kemungkinan penyebabnya.

Diagram sebab akibat juga berguna untuk membantu menyelesaikan permasalahan-permasalahan yang dihadapi dengan mengaitkan penyebabnya serta faktor-faktor yang mempengaruhinya.

Adapun faktor-faktor yang mempengaruhi dan menjadi penyebab kecacatan produk secara umum dapat digolongkan sebagai berikut: 1). Para karyawan atau operator yang bekerja dengan tugas yang terlibat dalam proses produksi. 2). Segala sesuatu yang akan dijadikan bahan dasar atau komponen produk yang akan dipergunakan atau diproduksi oleh perusahaan. 3). Peralatan atau berbagai perlatan yang digunakan untuk membuat produk. 4). Petunjuk atau instruksi kerja yang memuat perintah kerja yang harus diikuti dalam proses pembuatan sebuah produk. 5). 
Keadaan sekitar perusahaan yang secara langsung atau tidak langsung mempengaruhi perusahaan secara umum dan mempengaruhi proses produksi secara khusus.

Dalam sebuah perusahaan tentunya terdapat SOP (Standar Oprational Procedure) yang berlaku yang akan mengetahui apakah penerapannya sudah efektif atau belum efektif, hal ini akan terbukti dengan diagram sebab akibat yang di sebebkan oleh beberapa jenis kegagalan/produk cacat diantaranya yang disebabkan oleh rubber robek dapat dilihat pada Gambar 1, untuk jenis lekang/ boanding dapat dilihat pada Gambar 2, untuk jenis kegagalan kotor dapat dilihat pada Gambar 3 , untuk jenis kegagalan jahitan tidak rapi akan terlihat pada Gambar 4, sedangkan jenis kegagalan luntur dan aksesoris tertukar akan dilihat pada Gambar 5 dan Gambar 6.

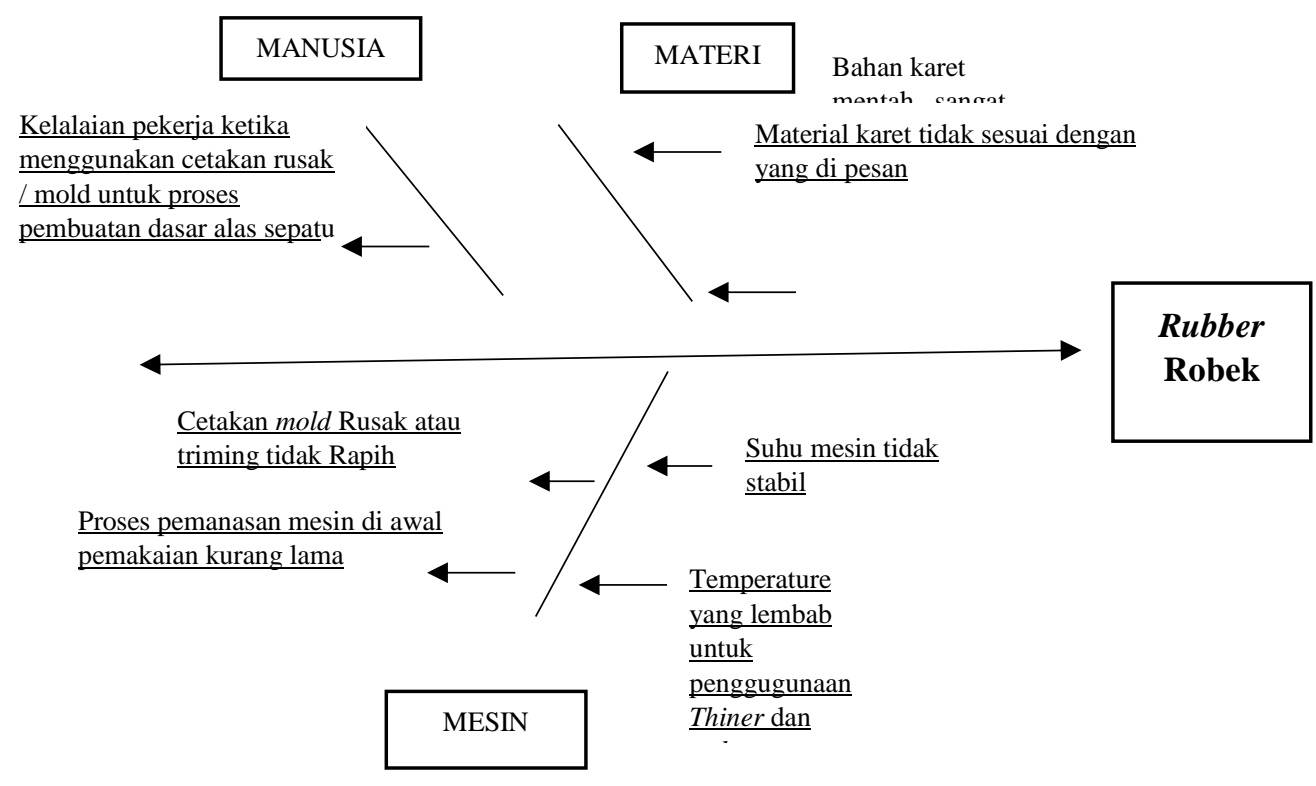

Sumber: Data diolah

Gambar 1.

Rubber Robek 


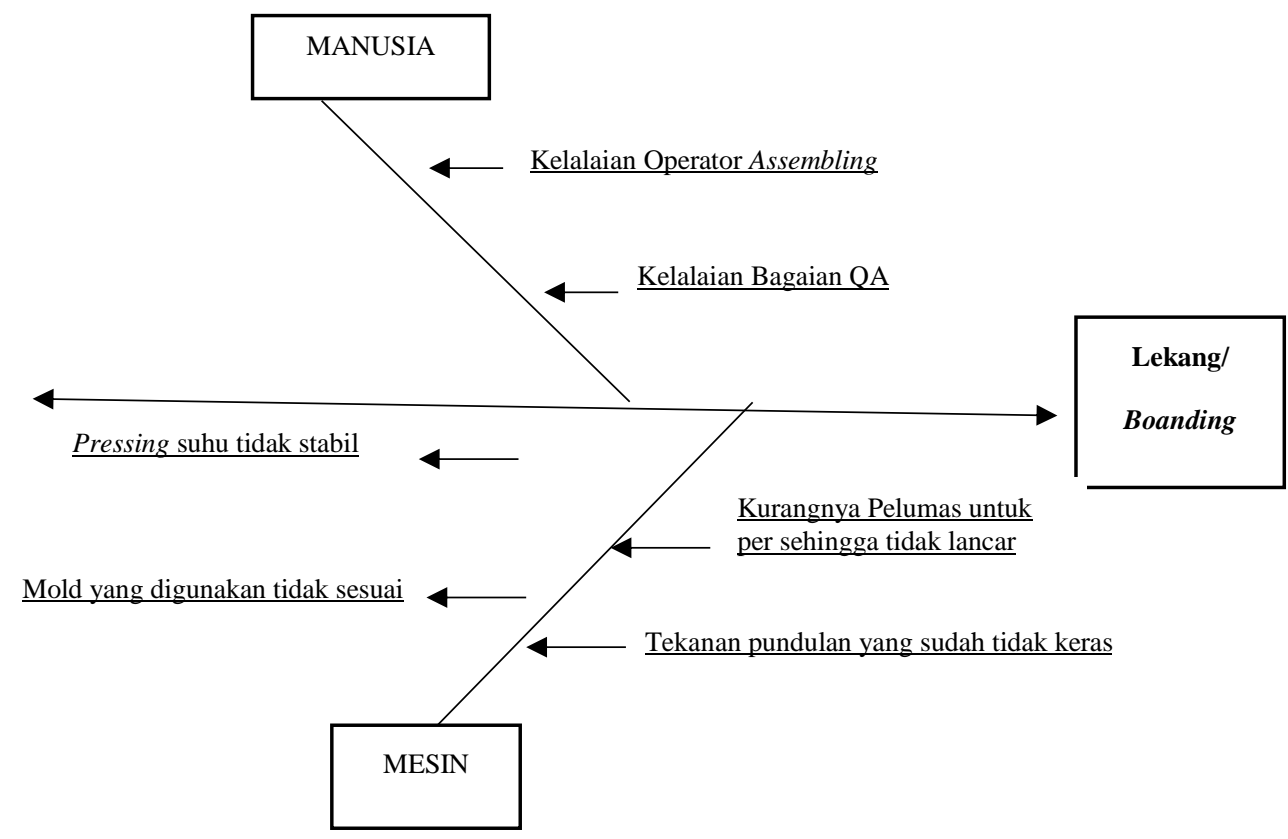

Sumber: Data diolah

Gambar 2.

Lekang / Bonding

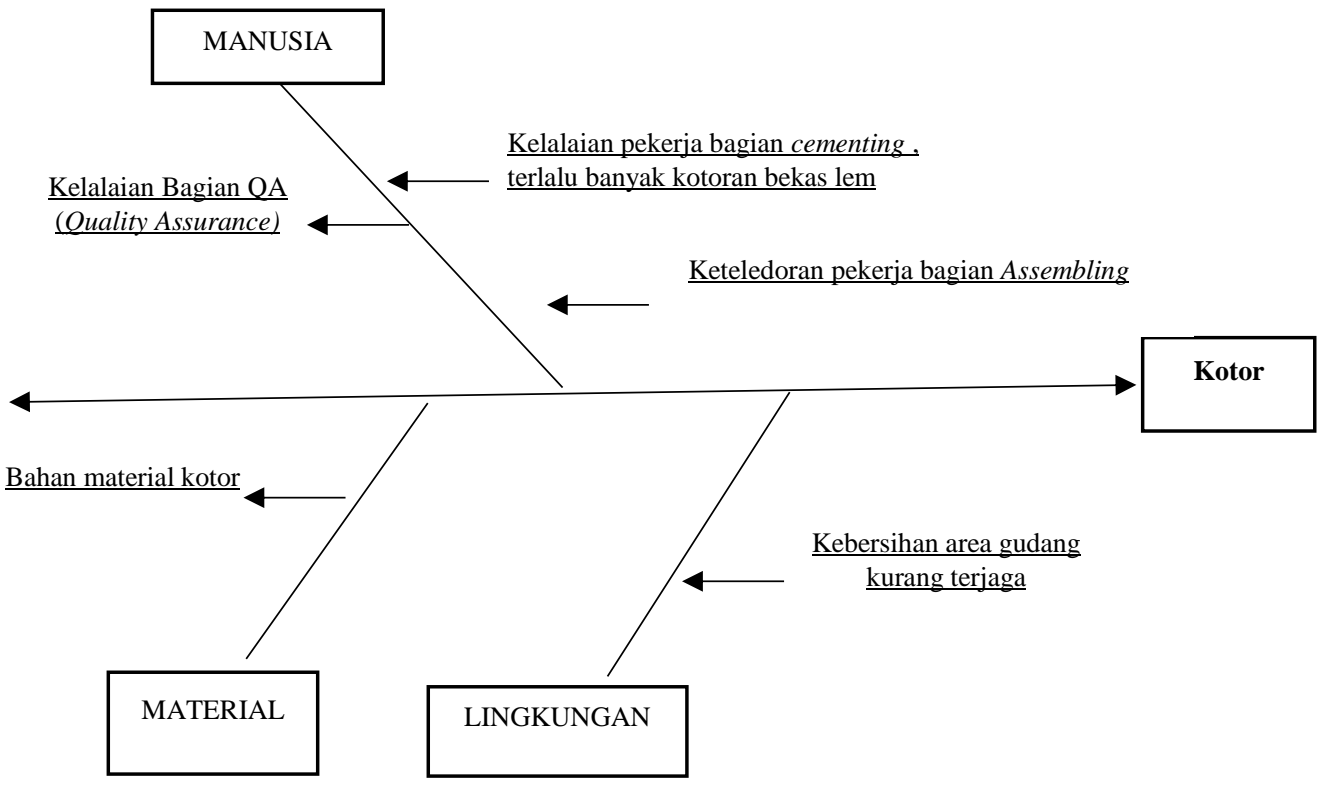

Sumber: Data diolah

\section{Gambar 3.}

Kotor 


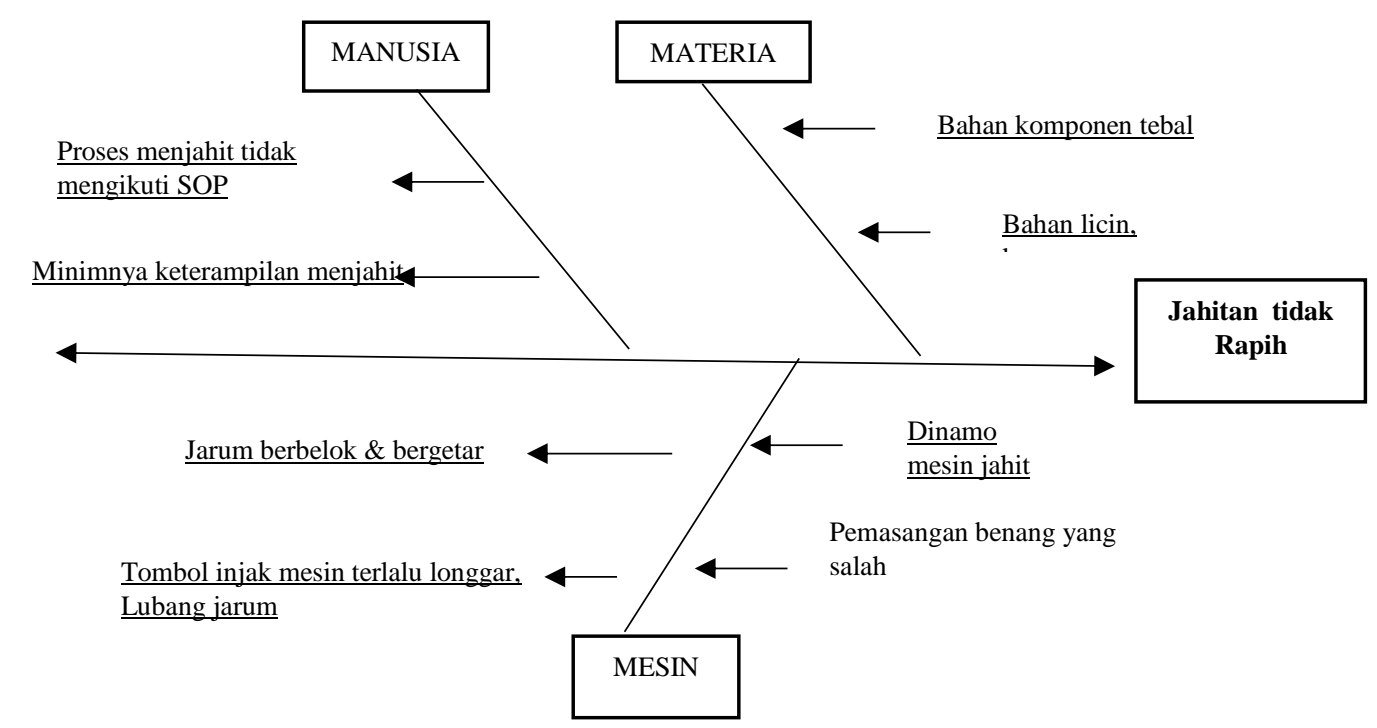

Sumber: Data diolah

Gambar 4.

Jahitan Tidak Rapih

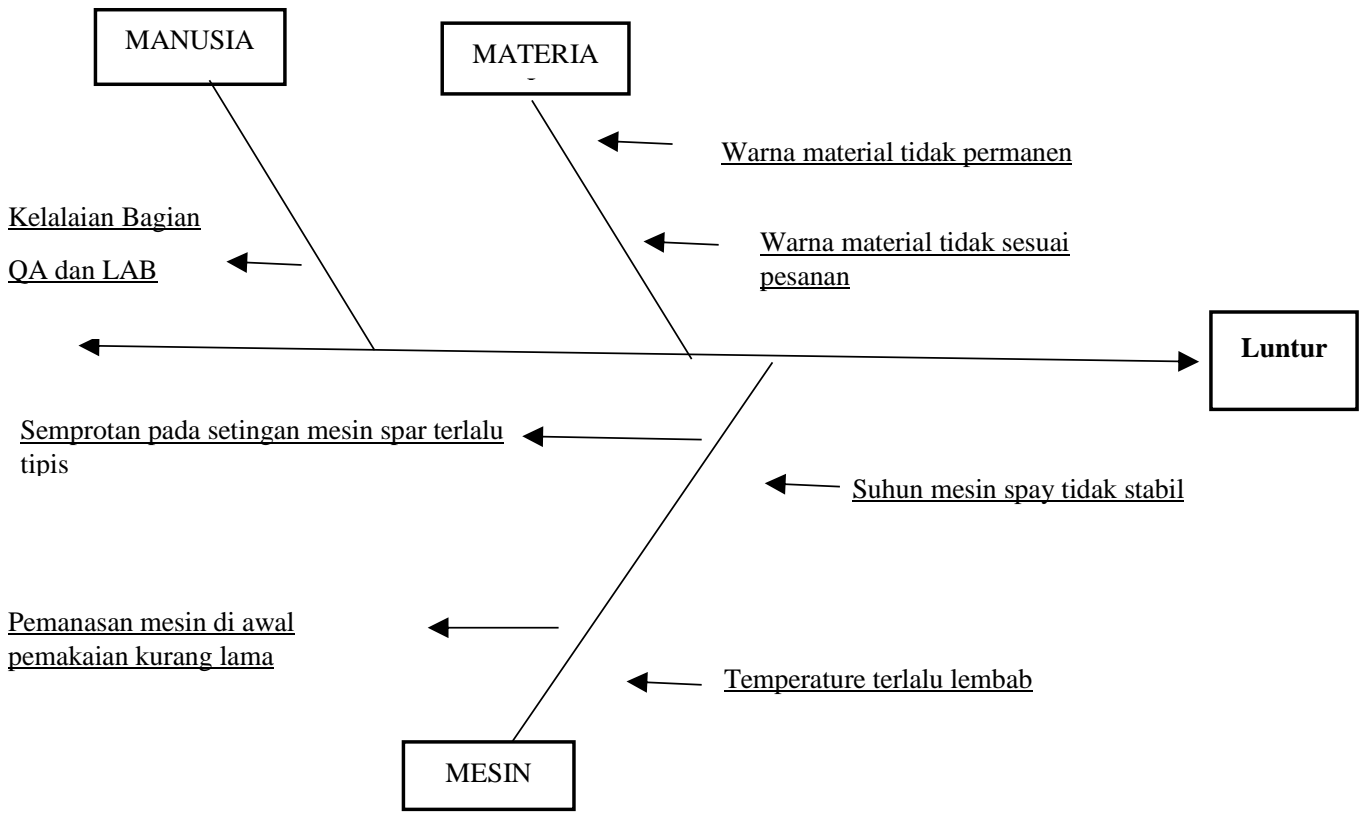

Sumber: Data diolah

Gambar 5.

Jenis Cacat Luntur 


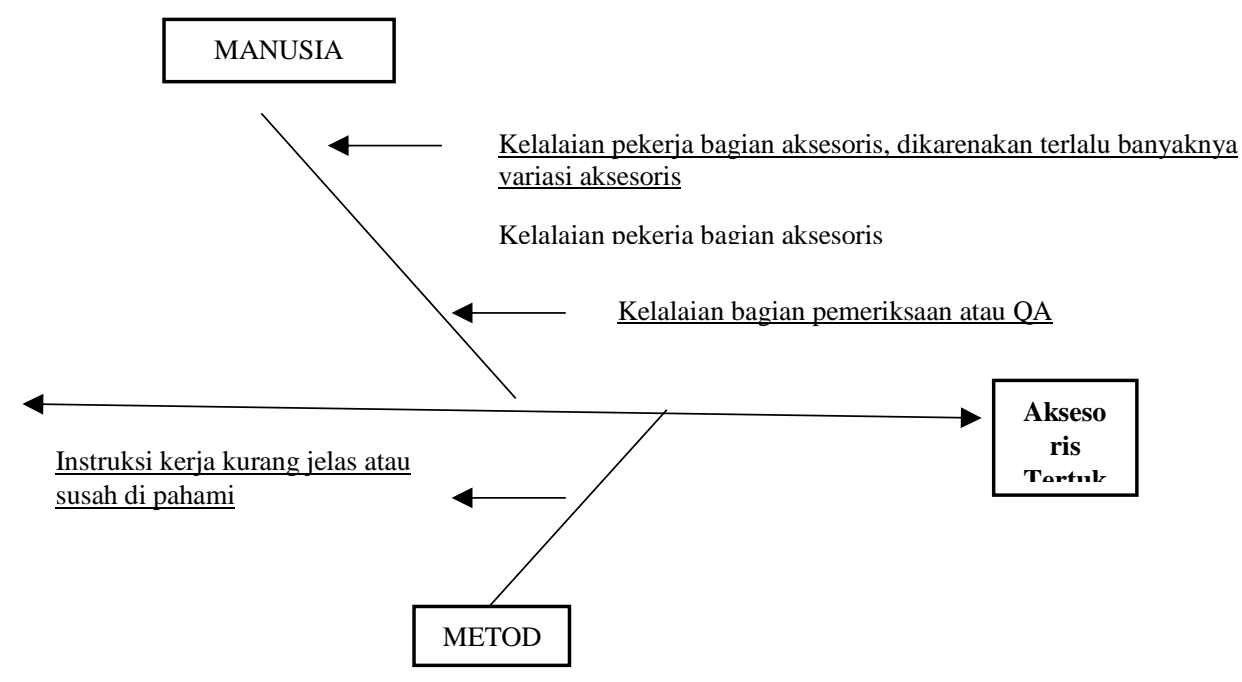

Sumber: Data diolah

Gambar 6.

Jenis Aksesoris Tertukar

Tabel 2.

Usulan Tindakan Untuk Kegagalan Jenis Rubber Robek

\begin{tabular}{|c|c|c|}
\hline & $\begin{array}{c}\text { Faktor } \\
\text { Penyebab }\end{array}$ & Usulan Tindakan Perbaikan \\
\hline Manusia & $\begin{array}{l}\text { Kelalaian pekerja } \\
\text { bagian rubber } \\
\text { - } \begin{array}{l}\text { Kurangnya ketelitian } \\
\text { bagian pengecekan } \\
\text { atau QA }\end{array}\end{array}$ & $\begin{array}{l}\text { Melakukan pengarahan yang lebih sering kepada para } \\
\text { karyawan khususnya pekerja bagian bottom atau } \\
\text { outsole. } \\
\text { Melakukan pemeriksaan oleh QA dan semua pekerja } \\
\text { harus mendapatkan pengarahan atau breffeng terlebih } \\
\text { dahulu sebelum memulai pekerjaan serta menempelkan } \\
\text { SOP disetiap area pekerjaan yang berhubungan dengan } \\
\text { pemeriksaan serta pengawasan oleh kepala bagian } \\
\text { produksi sesering mungkin menecek area pekerjaannya. }\end{array}$ \\
\hline Mate & $\begin{array}{ll}\text { - } & \text { Bahan tidak sesuai } \\
\text { dengan pesanan } \\
\text { Bahan terlalu } \\
\text { mentah dan tipis }\end{array}$ & $\begin{array}{l}\text { Melakukan pengecekan data ulang ketika akan memesan } \\
\text { barang baru, dan memastikan bagian purcahing tidak } \\
\text { membuat kesalahan. } \\
\text { Pemeriksaan ulang yang dilakuakn oleh bagian QA } \\
\text { sebelum barang di serahkan kepada pihak pemotongan } \\
\text { bahan atau cutting. }\end{array}$ \\
\hline Mesin & $\begin{array}{ll}\text { - } & \text { Suhu mesin tidak } \\
\text { stabil } \\
\text { - } & \text { Mesin kurang } \\
& \text { terawat } \\
\text { - } & \text { Cetakan mold rusak }\end{array}$ & $\begin{array}{l}\text { Melakukan setel ualang pengaturan temperature } \\
\text { mesin sebelum memulai pekerjaan } \\
\text { Mengarahkan karyawan untuk selalu membiasakan } \\
\text { diri merawat area kerjanya baik sebelum maupun } \\
\text { sesudah bekerja } \\
\text { Mengecek kesesuaian cetakan mold dan mengganti } \\
\text { cetakan mold yang sudah rusak. }\end{array}$ \\
\hline
\end{tabular}

Sumber: Data diolah 
Tabel 3.

Usulan Tindakan Untuk Kegagalan Karena Lekang atau Boanding

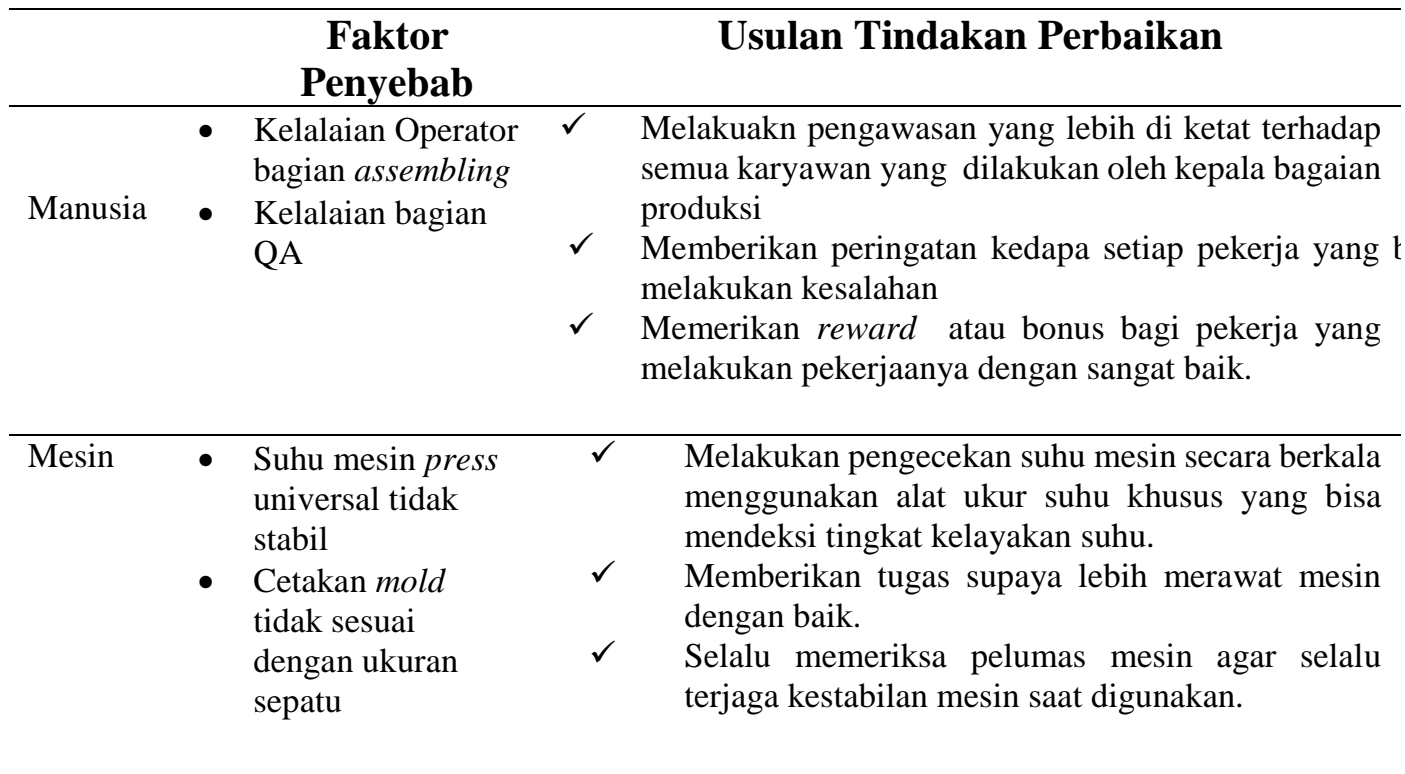

Sumber: Data diolah

Tabel 4.

Usulan Tindakan Untuk Kegagalan Karena Kotor

\begin{tabular}{|c|c|c|}
\hline & $\begin{array}{c}\text { Faktor } \\
\text { Penyebab }\end{array}$ & Usulan Tindakan Perbaikan \\
\hline Manusia & 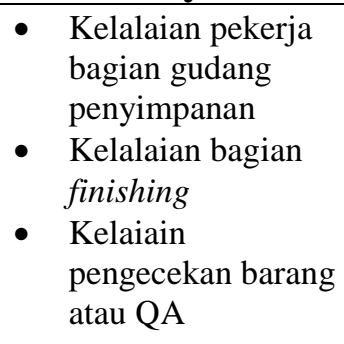 & $\begin{array}{l}\text { Melakukan pengarahan kepada karyawan bagian } \\
\text { penyimpanan atau gudang } \\
\checkmark \quad \text { Selalu memperingati bagian pengecekan agar selalu } \\
\text { fokus dalam mengawasi setiap jenis produk yang anak } \\
\text { diperiksa, dan memberikan pengarahan tentang } \\
\text { pentingnya kualitas dalam setiap hasil produk yang } \\
\text { dihasilkan. }\end{array}$ \\
\hline Material & - Material kotor & $\begin{array}{ll}\checkmark & \text { Melakukan pengecekan ulang bahan atau material } \\
\text { sebelum di produksi. } & \\
\checkmark & \text { Menyampakian keluhan kepada pemasok atau supplier. }\end{array}$ \\
\hline $\begin{array}{l}\text { Lingkun } \\
\text { gan }\end{array}$ & $\begin{array}{l}\text { Kebersihan Area } \\
\text { penyimpanan atau } \\
\text { gudang }\end{array}$ & $\begin{array}{l}\text { Menerapkan kebiasaan untuk selalu membersihkan area } \\
\text { kerjanya masing-masing khusunya kerapihan area kerja } \\
\text { bagian penyimpanan. }\end{array}$ \\
\hline
\end{tabular}

Sumber: Data diolah 
Tabel 5.

Usulan Tindakan Untuk Kegagalan Karena Jahitan Tidak Rapih

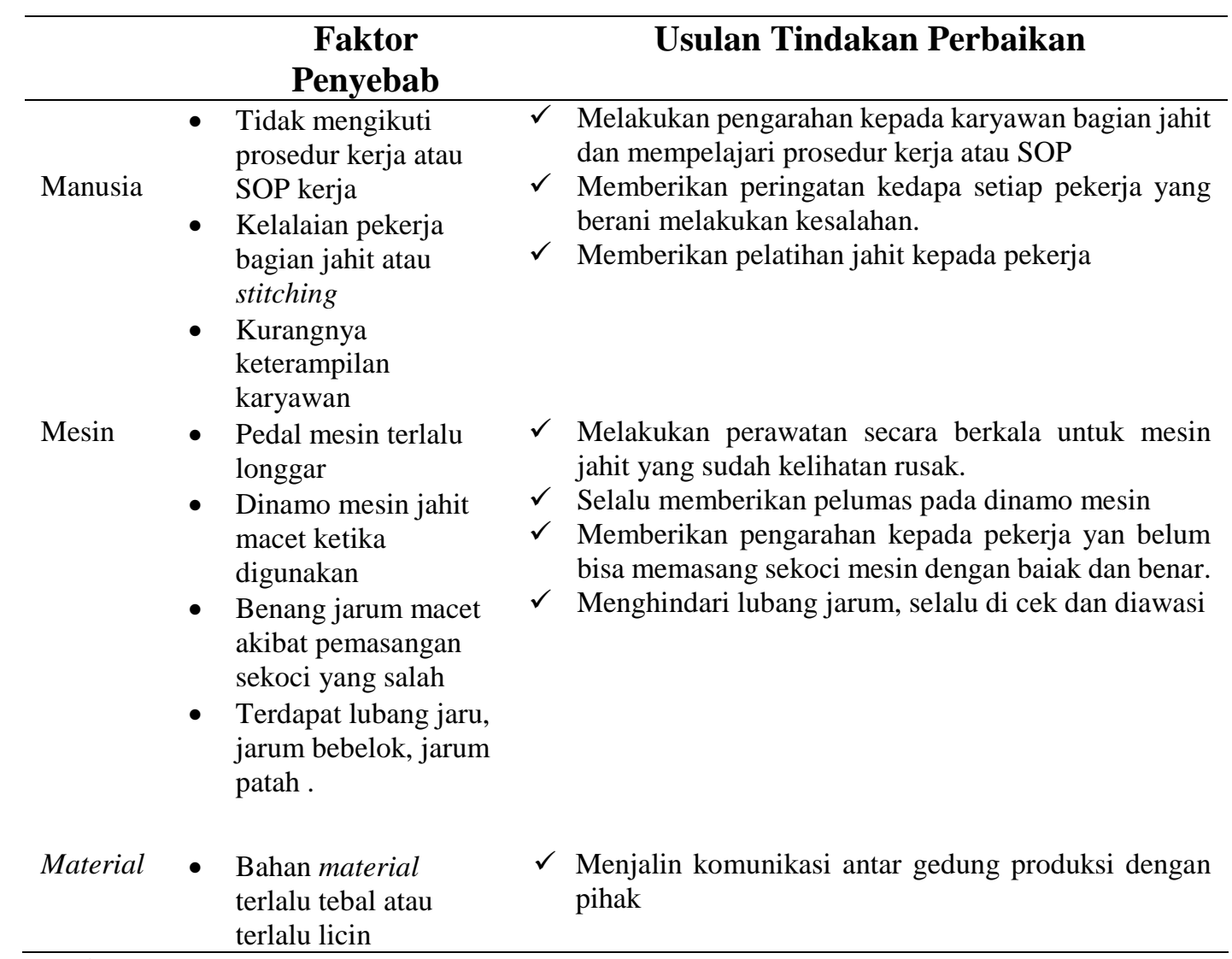

Sumber: Data diolah

Tabel 6.

Usulan Tindakan Untuk Kegagalan Karena Luntur

\begin{tabular}{|c|c|c|c|}
\hline & $\begin{array}{c}\text { Faktor } \\
\text { Penyebab }\end{array}$ & & Usulan Tindakan Perbaikan \\
\hline Material & $\begin{array}{l}\text { - Warna material } \\
\text { tidak permanen } \\
\text { Warna material } \\
\text { tidak sesuai dengan } \\
\text { yang dipesan. }\end{array}$ & $\checkmark$ & $\begin{array}{l}\text { cek pemesanan apakah sudah sesuai dengan } \\
\text { sample atau tidak } \\
\text { Selalu cek material dengan sample. }\end{array}$ \\
\hline Manusia & $\begin{array}{l}\text { - Kelalaian bagian } \\
\text { pengecekan atau } \\
\text { QA } \\
\text { - Kelalaian bagian } \\
\text { LAB }\end{array}$ & $\checkmark$ & $\begin{array}{l}\text { Memberikan sanksi kepada pihak QA, tentang } \\
\text { pentingnya kualitas. } \\
\text { Petugas bagain LAB harus lebih teliti lagi. }\end{array}$ \\
\hline
\end{tabular}


Tabel 7.

Usulan Tindakan Untuk Kegagalan Aksesoris Tertukar

\begin{tabular}{lllll}
\hline & \multicolumn{2}{c}{$\begin{array}{c}\text { Faktor } \\
\text { Penyebab }\end{array}$} & & Usulan Tindakan Perbaikan \\
\hline Manusia & $\begin{array}{l}\text { Kelalaian pekerja } \\
\text { bagian } \text { assembling } \\
\text { Kelalaian bagian } \\
\text { QA }\end{array}$ & $\checkmark$ & $\begin{array}{l}\text { Kepala bagian produksi harus melakukan } \\
\text { pengawasan yang ketat kepada semua pekerja. } \\
\text { Memberikan pengarahan kepada bagain QA } \\
\text { untuk selalu fokus terhadap pemeriksaan } \\
\text { kualitas. }\end{array}$ \\
Metode & $\begin{array}{l}\text { Intruksi kerja } \\
\text { kurang jelas }\end{array}$ & $\checkmark$ & $\begin{array}{l}\text { Kepala produksi harus membuat instruksi kerja } \\
\text { yang jelas dengan memberikan langkah- } \\
\text { langkah pengerjaan yang mudah dipahami. }\end{array}$ \\
\hline
\end{tabular}

Sumber: Data diolah

\section{SIMPULAN DAN SARAN}

Dapat disimpulkan bahwa penyebab penyimpangan kualitas pada PT.Pratama Abadi Industri (JX) Sukabumi yaitu terdapat enam jenis gambaran produk cacat yang terjadi pada perusahaan yaitu diantaranya jenis rubber robek, jenis lekang atau boanding, jenis kotor, jenis jahitan tidak rapih, jenis luntur dan disebabkan oleh aksesoris tertukar. Penyimpangan kualitas pada PT.Pratama Abadi Industri (JX) Sukabumi setelah di analisis menggunakan alat bantu statistik dengan menggunakan statustical quality control (sqc) dengan alat 7 alat bantu (seven tools) didapatkan masalah paling besar yaitu dari sekian kerusakan yang terjadi yang paling berpengaruh adalah jenis kerusakan yang disebabkan oleh jenis cacat jahitan tidak rapih pada produk sepatu kejadian ini dapat disebabkan oleh kesalahan manusia (humman error) serta penyebab faktor lainnya seperti rendahnya kualitas material, kerusakan mesin serta masih kurangnya pemahaman metode atau cara bekerja pada karyawan. Untuk mengendalikan kualitas produk akhir sepatu, maka 
harus dilakukan usulan perbaikan guna mencegah timbulnya kegagalan yang disebabkan oleh 4 faktor penyebab produk cacat yaitu: manusia,material, mesin dan metode atau proses.

Meminimalkan proses perbaikan data cacat produk dengan memperbaiki bila masih ada yang bisa diperbaiki seperti pada beberapa jenis sepatu yang masih bisa di produksi kembali yaitu pada jenis kerusakan yang disebabkan oleh jenis rubber robek, jenis lekang atau boanding, jenis kotor, jenis jahitan tidak rapih, jenis luntur dan disebabkan oleh aksesoris tertukar. Memberikan pelatihan khusus kepada karyawan guna meminimalisi jenis cacat yang kemungkinan sering terjadi yaitu untuk jenis kerusakan yang disebabkan oleh jenis cacat jahitan tidak rapih pada produk serta peantauan secara khusus untuk penggunaan statistik menggunakan statustical quality control (sqc) dengan alat 7 alat bantu (seven tools) agar memaksimalkan pelaksanaan pengendalian mutu pada perusahaan. Memberikan masukan usulan perbaikan menyeluruh mulai dari perbaikan kualitas karyawan dengan memberikan pelatihan kerja, untuk material melakukan pemeriksaan bahan baku lebih teliti, untuk mesin melalukan perawatan mesin yang lebih konsisten, dan untuk metode atau cara kerja melakukan pelatihan atau training yang lebih lengkap dari perusahaan.

\section{REFERENSI}

Assauri, Sofjan., (1998). Manejemen Produksi dan Operasi.Jakarta : Fakultas Ekonomi Universitas Indonesia.Vol.8,No.1.

Assauri, Sofjan,.(2014). Manajemen Pemasaran. Raja Grafindo Persada : Jakarta 
Anis, M,. Dan Widyaningrum, R. (2013). Penggunaan metode new seven tools untuk pengendalian kualitas produk. Jurnal Tekhnik Industri, Universitas muhammadiyah Surakarta.

Bustami, B., dan Nurlela. (2007). Akuntansi Biaya Teori \& Aplikasi. (Yogyajarta: Graha ilmu).

Danial,R.Deni M.et.al.,(2013) Pedoman Penulisan Skripsi.Sukabumi:Program Studi Administrasi Bisnis Fakultas Ilmu Administrasi Bisnis Dan Humaniora Universitas Muhammadiyah Sukabumi.

Gasperz, V. (2003). Metode Analisis Untuk Peningkatan Kualitas. Jakarta : PT. Gramedia Pustaka Utama, Cetakan kedua.

Halim, Abdul. (2000). Akuntansi Biaya. Yogyakarta: Erlangga

Hatani, La.(2008). Manajemen Pengendalian Mutu Produksi Roti Melalui Pendekatan Statistical Quality Control(SQC).Jurusan ManajemenFEU.

Indri,C.P., Mandar, R.S. (2012). Pengendalian Kualitas Produk Cacat dengan Pendekatan Kaizen dan Analisis Masalah Dengan Seven Tools : Prosiding Seminar Nasional Aplikasi Sains dan Teknologi "(SNAST) periode III, Yogyakarta 3 November 2012.

Khodijah, S.L (2015). Analisis faktor-faktor penyebab kerusakan produk pada proses cetak produk (Studi Kasus Pada Majalah Sakinah PT Temprina Media Grafika Jawa Pos Semarang). Skripsi Sarjana Pada Fakultas Ekonomi dan Bisnis Universitas Diponogoro: Tidak diterbitkan.

Kholmi, M., dan Yuningsih,. (2009). Akuntansi Biaya. Malang : UMM

Montgomery, Douglas C. (2001). Introduction to Statistical Quality Control.4.4 Edition. New York : John Wiley \& Sons, Inc.

Mulyadi. (2001). Sistem Akuntansi. Penerbit: Jakarta : salemba empat . (2009). Akuntansi Manajemen. Edisi keempat. Penerbit Universitas Gadjah Mada YKPN: Yogyakarta.

Nastiti, H.(2014). "Analisis Pengendalian Kualitas Produk Dengan Metode Statistical Quality Control”. Jurnal Teknik Industri. 01. (04). 1-12.

Poerwanto, H.G,. (2014) Aktivitas Situs Terkini : Legalitas. (online) Tersedia di:https://sites.google.com/site/kelolakualitas/Pengendalian-Kualitas-

Statistik/Aktivitas Situs Terkini/. (Diaskes Pada 13 Mei 2019). 
Setiawan, A., Khoil, M. 2015. “Analisis Pengendalian Kualitas Untuk Mengurangi Cacat Produk Dengan Menggunakana Metode Statistical Process Control (SPC)". Makalah Teknik Industri Marcubuana, Jakarta.

Suharto,S.B., Asysyfa, R.H.(2013). "Analisa Pengendalian Kualitas Dengan Menggunakan Metode Statistical Quality Control (SQC)”. Jurnal Teknik Industri.02.(01). 29-36.

Sukmadinata. (2005). Metodologi Penelitian Bisnis untuk Akuntansi dan Manajemen. Yogyakarta: BPFE

Sugiono. (2010). Metodologi Penelitian Bisnis. Bandung : Alfabeta.

Sugiyono. (2014). Metode Penelitian Bisnis Pendekatan Kuantitatif, Kualitatif, dan $R \& D$. Bandung: Alfabeta.

Tjiptono, F., dan Diana, A. (2001). Total Quality Manajemen edisi revisi. Penerbit ANDI. Yogyakarta. 